\title{
PROTOCORM-LIKE BODIES AND PLANT REGENERATION FROM FOLIAR EXPLANTS OF COELOGYNE FLACCIDA, A HORTICULTURALLY AND MEDICINALLY IMPORTANT ENDANGERED ORCHID OF EASTERN HIMALAYA
}

\author{
KaLyan K. De ${ }^{1} \&$ Sujit Sil \\ Post Graduate Department of Botany, Hooghly Mohsin College \\ Chinsurah -712 101, Hooghly, West Bengal, India \\ ${ }^{1}$ Author for correspondence: kalyannet2003@yahoo.co.in
}

\begin{abstract}
Aвstract. An efficient induction of protocrom-like bodies (PLBs) and plantlet regeneration from the young leaves of in vitro grown seedlings of Coelogyne flaccida, an horticulturally and medicinally important endangered epiphytic orchid, was accomplished in order to develop mass-scale propagation. The young leaves $(1.5 \mathrm{~cm}$ in length) from 110 days old aseptically germinated seedling were grown in vitro in Murashige and Skoog's (MS) medium supplemented with different concentrations and combinations of NAA ( $0.5-2 \mathrm{mg} / \mathrm{L})$, BAP $(0.5-2$ $\mathrm{mg} / \mathrm{L})$ and $\mathrm{Kn}(0.5-2 \mathrm{mg} / \mathrm{L})$. The explants produced protocorm-like bodies directly from the epidermal cells of leaf without the formation of intervening callus tissue within four weeks of culture. The highest number of plantlets regenerated through PLBs per explant after 15 weeks was 35-36 in presence of NAA (2mg/l) and Kn (2mg/l). Within 20-25 weeks individual plantlets produced 2-3 leaves and 2-3 roots. Chromosome number from all plants regenerated from leaf explants showed the same chromosome number as the mother plant as $2 n=40$. During acclimatization, $80 \%$ of the plantlets survived after one month of transplantation.
\end{abstract}

Key Words: Coelogyne flaccida, foliar explant, micropropagation

Introduction. Coelogyne flaccida Lindl. is one of the most beautiful horticulturally important orchids native to Nepal, India, Myanmar, West China and Laos. It occurs as an epiphytic herb in the sub-tropical regions at the elevations of 900-2300 m (Clayton 2002). The pseudobulbs of this orchid bear a pair of linear, lanceolate leaves at the apex. The inflorescence is of a pendulous recemose type arising from the base of pseudobulb. The mildly scented long lasting flowers (3-5 cm across) are white with yellow on the middle of the lip, stripped red in the side lobes and spotted red at the base of the middle lobe. The beautiful flowers of this orchid have high ornamental value as a cut flower which has made it popular. It has resulted in over collecting. This factor along with a shrinking natural habitat is putting pressures on the survival of the species. In addition to this, orchids are very slow growing plants which has added to their being rare and endangered (Bailes 1985, Wu et al. 2009). Besides their horticultural importance, the genus Coelogyne in general, has some therapeutic value. It is mainly used for the treatment of tuberculosis, but different species of Coelogyne have some other uses in herbal medicine for example the pseudobulb and leaf of C. flaccida are used to treat headache and indigestion (Rajbhandari \& Bhattarai 2001). The active principle isolated from this orchid is a new type of stilbenoides designated as callosin whose chemical structure was established as 2, 6 dihydroxy-4, 7 dimethoxy-9, 10 dihydrophenanthrene (Majumdar et al. 1995). Therefore, to overcome the danger of extinction of such a horticulturally and medicinally important orchid and to prevent illegal collection from wild, it is urgently needed to develop rapid clonal propagation method for their resurrection in terms of conservation in their wild habitat.

Commonly, shoot tip or apical meristem is used for in vitro clonal propagation of orchids. Leaves are also preferable as a source of explants for clonal propagation (Arditti \& Ernst 1993, Nayak et al. 1997, Chen et al.1999, 2004, 2006, Park et al. 2002, Pathak \& Vij 2001, Seeni \& Latha 2000, Vij \& Aggarwal 2003, Vij \& Pathak 1990, Vij et al. 2000, 2002, Kai et al. 2008, Gow et al. 2009, Mayer et al. 2010, Naing 
et al. 2011). The shoot tip culture of orchids for clonal propagation entails the sacrifice of whole plants or the entire new growth. However, the use of leaf tissue has the advantage of not endangering or even seriously damaging a plant. In this study, the authors report the development of an efficient simple and reproducible one step protocol for getting large scale in vitro clonal plantlets of C. flaccida from young leaf explants via induction of PLBs directly without the formation of intervening callus tissue and the successful transplantation of plantlets to the ex vitro condition.

Materials and methods. The green undehised capsules (60-63 days after pollination) were collected from their natural habitat of mother plant from Kalimpong area (1247 $\mathrm{m}$ above sea level, Latitude $27.06^{\circ}$, Longitude $88.47^{\circ}$ ) of Darjeeling hill which is a part of Eastern Himalaya. The immature seeds were scooped out from the surface-sterilized and dissected capsule and germinated aseptically in Orchimax medium (Duchefa Biochemie BV product no. 0 0257) supplemented with $1 \mathrm{mg} / \mathrm{L}$ NAA and $15 \%$ coconut water for the preparation of aseptic plantlets. The seeds were incubated under dark condition at the temperature of $20^{\circ} \mathrm{C} \pm 2{ }^{\circ} \mathrm{C}$.

Immature leaves (1.5 cm in length) of 110 days old aseptic plantlets maintained in sterile culture were taken as explants for in vitro culture in Murashige \& Skoog's (MS) medium (1962) supplemented with different concentrations and combinations of NAA ( $0.5-2 \mathrm{mg} / \mathrm{L})$, BAP ( 0.5-2 mg/L) and $\mathrm{Kn}$ ( 0.5-2 mg/L ) as shown in Table 1 and a control set was maintained in parallel in the basal medium which is free from plant growth regulators. The $\mathrm{pH}$ of the media was adjusted to 5.65. The young leaves taken from the axenic plantlets were aseptically inoculated (one or two leaves per culture tube containing $20 \mathrm{ml}$ medium) and cultures of 380 tubes ( $25 \mathrm{~mm}$ diameter $\mathrm{x} 150 \mathrm{~mm}$ length) were incubated at $20^{\circ} \mathrm{C} \pm 2{ }^{\circ} \mathrm{C}$ under 16 hours photoperiod from cool white light giving $2659 \mu \mathrm{mol} \mathrm{m} \mathrm{m}^{-1} \mathrm{~s}^{-1}$ at culture level. The culture of one tube constitutes one replication and for each combination and concentration of plant hormones as shown in Table 1, twenty tubes of culture were made. The experiments were repeated twice following the same methodology and keeping the same culture condition. The response of each explant in each culture tube were carefully examined every day and frequently by microscopic observation. For counting the number of PLBs or number of plantlets when it was needed, the responding leaf explant was conveniently dissected into a number of pieces and the total number of PLBs or all regenerated plantlets per explants was examined and counted physically under dissecting microscope. Every 30 days interval each culture was sub-cultured into fresh medium keeping the same respective hormone combination and concentration. Experimental data was collected quantitatively or qualitatively on the basis of initiation of response or nature of response of explants in terms of time period of culture. After regeneration of plantlets with roots, they were finally sub-cultured in $250 \mathrm{ml}$ glass bottles containing $1 / 2$ strength MS medium without supplementation of any hormone and sugar. On reaching a height $60-65 \mathrm{~mm}$, the plantlets with three or four well-developed roots were taken out of the culture, washed thoroughly to remove all remnants of agar gel under running tap water and were finally potted in wetted coconut husk for acclimatization. The pots were maintained under mist and $50 \%$ shade for 2 months and after that they were moved to standard green house conditions.

The fresh roots of the donor plants and regenerated plants were pretreated with the mixture of saturated Paradichlorobenzene (p-DB) and 8-hydroxyquinolene (1:1) for 4 hours at $14-16{ }^{\circ} \mathrm{C}$ temperature, followed by washing and fixation in acetic-ethanol (1:3) for overnight. The root tips were kept in $45 \%$ acetic acid solution for 1 minute and stained with $2 \%$ aceto-orcein stain and $1(\mathrm{~N})$ HCL (9:1). Finally root tips were squashed in $45 \%$ acetic acid and the chromosome number of mitotic metaphase was counted.

Results. About $90 \%$ of the seeds of C. flaccida were successfully germinated under in vitro condition in the Orchimax medium supplemented with $1 \mathrm{mg} / \mathrm{L}$ NAA and $15 \%$ coconut water. Typically a seed gave rise to a PLB, which in turn developed into a seedling after 45 days of culture and then they were moved to light condition and under 16 hours photoperiod.

Since the plantlets of $C$. flaccida were obtained from the aseptically germinated seeds and grown under controlled in vitro condition, the plantlets were contamination free and physiologically uniform and stable. So, the explants were ideally procured from in vitro grown plantlets for the present investigation. In 
Table 1. In vitro plant regeneration response of $C$. flaccida foliar explants on MS medium.

\begin{tabular}{|c|c|c|}
\hline $\begin{array}{l}\text { MS Basal medium supplemented with } \\
\text { Hormones }\end{array}$ & $\begin{array}{c}\text { No. of PLB loci during } \\
\text { initiation of response } \pm \text { SE } \\
\text { after } 6 \text { weeks of inoculation of } \\
\text { leaf explant }\end{array}$ & $\begin{array}{l}\text { No. of plantlets/explant obtained from } \\
\text { PLBs after } 15 \text { weeks } \pm \text { SE }\end{array}$ \\
\hline $\mathrm{NAA}(0.5 \mathrm{mg} / \mathrm{L})+\mathrm{BAP}(0.5 \mathrm{mg} / \mathrm{L})$ & $1.80 \pm 0.28$ & $3.20 \pm 0.96$ \\
\hline $\mathrm{NAA}(0.5 \mathrm{mg} / \mathrm{L})+\mathrm{BAP}(1 \mathrm{mg} / \mathrm{L})$ & $2.30 \pm 0.29$ & $12.50 \pm 2.09$ \\
\hline $\mathrm{NAA}(0.5 \mathrm{mg} / \mathrm{L})+\mathrm{BAP}(2 \mathrm{mg} / \mathrm{L})$ & $3.60 \pm 0.078$ & $20.80 \pm 2.39$ \\
\hline $\mathrm{NAA}(1 \mathrm{mg} / \mathrm{L})+\mathrm{BAP}(0.5 \mathrm{mg} / \mathrm{L})$ & $1.20 \pm 0.28$ & $3.10 \pm 2.29$ \\
\hline $\mathrm{NAA}(1 \mathrm{mg} / \mathrm{L})+\mathrm{BAP}(1 \mathrm{mg} / \mathrm{L})$ & $3.90 \pm 0.79$ & $20.90 \pm 2.8$ \\
\hline NAA (1 mg/L) + BAP (2 mg/L) & $3.10 \pm 0.69$ & $24.70 \pm 2.68$ \\
\hline $\mathrm{NAA}(2 \mathrm{mg} / \mathrm{L})+\mathrm{BAP}(0.5 \mathrm{mg} / \mathrm{L})$ & $2.20 \pm 0.29$ & $3.60 \pm 0.79$ \\
\hline NAA (2 mg/L) + BAP (1 mg/L) & $3.60 \pm 0.078$ & $22.70 \pm 1.76$ \\
\hline NAA (2 mg/L) + BAP (2 mg/L) & $3.90 \pm 0.79$ & $27.80 \pm 2.39$ \\
\hline $\mathrm{NAA}(0.5 \mathrm{mg} / \mathrm{L})+\mathrm{Kn}(0.5 \mathrm{mg} / \mathrm{L})$ & $1.60 \pm 0.28$ & $3.70 \pm 0.78$ \\
\hline NAA (0.5 mg/L) + Kn (1 mg/L) & $2.20 \pm 0.29$ & $11.30 \pm 1.8$ \\
\hline $\mathrm{NAA}(0.5 \mathrm{mg} / \mathrm{L})+\mathrm{Kn}(2 \mathrm{mg} / \mathrm{L})$ & $3.70 \pm 0.49$ & $23.70 \pm 1.39$ \\
\hline $\mathrm{NAA}(1 \mathrm{mg} / \mathrm{L})+\mathrm{Kn}(0.5 \mathrm{mg} / \mathrm{L})$ & $2.10 \pm 0.39$ & $6.60 \pm 1.09$ \\
\hline $\mathrm{NAA}(1 \mathrm{mg} / \mathrm{L})+\mathrm{Kn}(1 \mathrm{mg} / \mathrm{L})$ & $3.80 \pm 0.78$ & $28.80 \pm 1.68$ \\
\hline $\mathrm{NAA}(1 \mathrm{mg} / \mathrm{L})+\mathrm{Kn}(2 \mathrm{mg} / \mathrm{L})$ & $3.90 \pm 0.79$ & $29.40 \pm 2.09$ \\
\hline $\mathrm{NAA}(2 \mathrm{mg} / \mathrm{L})+\mathrm{Kn}(0.5 \mathrm{mg} / \mathrm{L})$ & $2.20 \pm 0.29$ & $8.60 \pm 1.19$ \\
\hline $\mathrm{NAA}(2 \mathrm{mg} / \mathrm{L})+\mathrm{Kn}(1 \mathrm{mg} / \mathrm{L})$ & $4.10 \pm 0.89$ & $32.10 \pm 2.47$ \\
\hline $\mathrm{NAA}(2 \mathrm{mg} / \mathrm{L})+\mathrm{Kn}(2 \mathrm{mg} / \mathrm{L})$ & $4.20 \pm 0.89$ & $35.30 \pm 2.51$ \\
\hline
\end{tabular}

the basal medium i.e. medium without supplemented any plant growth regulators, the explants exuded, turned brown and perished within two months. In case of hormone added media, the first noticeable change of the explants under in vitro condition was the swelling and enlargement of the basal portion of the leaf within four weeks (Fig. 1A). After one month, the hand-made thin anatomical sections of the swelled portion of the explants microscopically revealed the appearance of small green protuberances (Fig. 1B) from the epidermal region. Such protuberances were ultimately transformed directly into protocorm like bodies (PLBs) in course of growth and development after six weeks without the formation of intervening callus tissue. In all cases, the PLBs were formed initially at the basal region of the foliar explants. However, in some cases depending on higher concentration of hormones (NAA
1-2 mg/l plus BAP 1-2 mg/l or Kn 1- $2 \mathrm{mg} / \mathrm{l}$ ), more PLBs formation were induced and found to grow gradually towards apical part from basal region along both margins of the foliar explant.

Table 1 shows the number of PLB formation after 6 weeks and regeneration of plantlets per explants after 15 weeks in different hormone concentration and combination. The maximum number of plants were yielded after 15 weeks was 24-27 in presence of NAA $(1 \mathrm{mg} / \mathrm{l})$ plus BAP $(2 \mathrm{mg} / \mathrm{l})$ and NAA $(2 \mathrm{mg} / \mathrm{l})$ plus BAP $(2 \mathrm{mg} / \mathrm{L})$ combinations respectively and the lowest number from plant regeneration after 15 weeks was 3-4 in presence of NAA $(0.5 \mathrm{mg} / \mathrm{l})$ and BAP $(0.5 \mathrm{mg} / \mathrm{l})$ combination. On the other hand, NAA $(0.5 \mathrm{mg} / \mathrm{l})$ in combination with $\mathrm{Kn}(0.5 \mathrm{mg} / \mathrm{l})$ supported very low number of plantlets (3-4) regeneration per explants through a PLB mediated response, but when keeping 

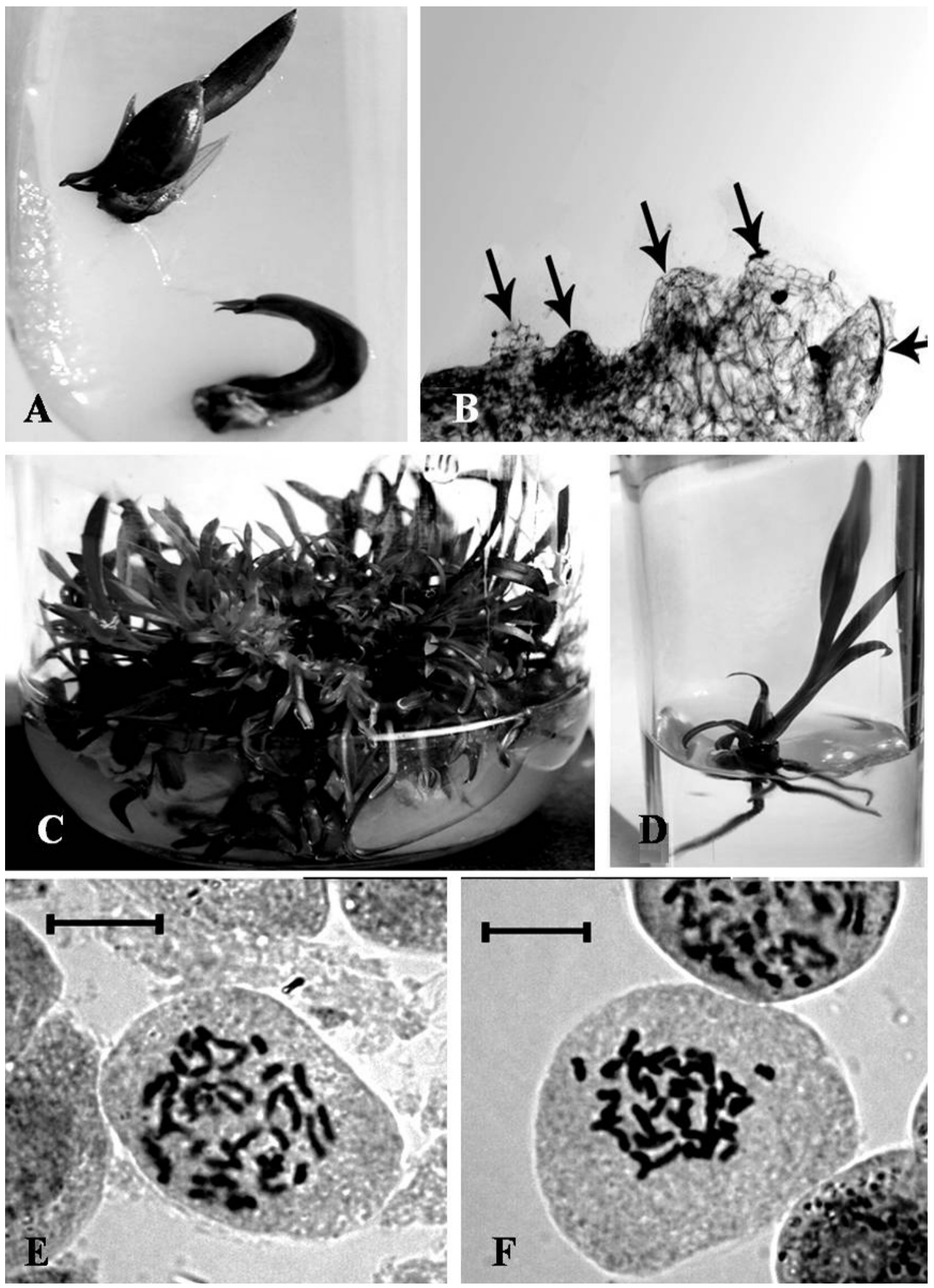
the same concentration of NAA i.e. $0.5 \mathrm{mg} / \mathrm{l}$, the concentrations of $\mathrm{Kn}$ combination was changed and increased from $0.5 \mathrm{mg} / \mathrm{l}$ to either $1 \mathrm{mg} / 1$ or $2 \mathrm{mg} / \mathrm{l}$ in the media, the regeneration response was also significantly enhanced. The maximum regeneration response and the highest number of plantlets regeneration mediated through PLBs per explants (35-36) after 15 weeks were obtained in the medium supplemented with NAA $(2 \mathrm{mg} / \mathrm{l})$ and $\mathrm{Kn}(2 \mathrm{mg} / \mathrm{l})$. Therefore, the efficiency of $\mathrm{Kn}$ at the concentration of $2 \mathrm{mg} / \mathrm{l}$ in combination with $\mathrm{NAA}(2 \mathrm{mg} / \mathrm{l})$ in terms of regeneration response and the number of plantlets regeneration per foliar explants of Coelogyne flaccida after 15 weeks were found better than that of same concentration of NAA and BAP used for the same purpose. When a clump of approximately 50 PLBs were separated and sub-cultured monthly upto 40 weeks in $250 \mathrm{ml}$ glass bottles containing the same medium i.e. supplemented with NAA ( $2 \mathrm{mg} / \mathrm{l})$ and $\mathrm{Kn}$ $(2 \mathrm{mg} / \mathrm{l})$, the number of plantlets was further increasing by multiplication of PLBs and ultimately became uncountable number (Fig. 1C). However, in case of other media supplemented with different combination and concentration of NAA and BAP or Kn, further subculture upto 40 weeks also increased the number of plantlets comparatively at a slower rate. Initially three to four roots per plantlet were emerged (Fig. 1D). Chromosome number from all plants regenerated from leaf explants were counted and revealed that indeed the plants showed the same chromosome number as mother plant as $2 \mathrm{n}=40$ (Fig. 1E, F). The plantlets showed $80 \%$ survival rate when subjected to a very careful treatment for acclimatization.

Discussion. In the present investigation, young leaves were selected as the young tissue is known to regenerate better owing to their less rigid cell walls. The regeneration and proliferation competence of the juvenile leaves is much more than the relatively older explants. Plant regeneration from young leaf tissue could be induced either indirectly through the formation of intervening callus tissue (Hong et al. 2008, Huang \& Chung 2010, Ng \& Saleh 2011) or directly through the formation of protocorm-like bodies ( Luo et al. 2008, Mayer et al. 2010, Naing et al. 2011). Regeneration of PLBs is comparable to the somatic embryogenesis pathway in orchids (Morel 1974). So, propagation by direct formation of PLBs from the leaf tissue is a preferred option because of the large number of PLBs that can be obtained within a short period of time. PLBs can proliferate rapidly and can readily regenerate into complete plantlets; so they are also the most general target tissue for genetic transformation in orchids (Liau et al. 2003, Sreeramanan et al. 2008). Moreover, PLBs are welldifferentiated tissues that are sometimes regarded as orchid embryos that can develop two distinct bipolar structures, namely, the shoot and root meristem. Thus, these structures are able to convert to plantlets easily (Ng \& Saleh 2011).

The pathway of response of an explant in culture preferably depends on the exogenous level of plant growth regulators. Callus induction from leaf segment of orchids is more difficult than any other meristemed explant. However, juvenile leaves have the possibility to form the callus tissue because of its potential meristimatic nature and it also depends on the presence of growth stimulus in nutrient pool. Moreover, tissue cultures of orchids have not been focused on callus because of their slower growth rate and increased necrosis during culture (Zhao et al. 2008). In the present study, we succeeded in getting PLBs directly from the leaf tissue instead of callus stage. Similar result has been demonstrated for Aerides crispa Lindl. (Sheelavanthmath et al. 2005). Juvenile explants like young leaves were important for the efficient induction of PLBs and the subsequent regeneration of plants in Aerides crispa. Lee \& Phillips (1988) attributed this point as being of major importance because plants produced by direct regeneration via PLB formation will exhibit greater genetic stability than those produced by callus. Seeni and Latha (1992) regenerated a large number of phenotypically uniform plants from the basal part of the young leaf of flowering Red Vanda.

The types and concentrations of plant growth

Left, FIGURE 1. Direct plant regeneration from foliar explants of Coelogyne flaccida. (A) Swelled and enlarged leaf explants in nutrient medium after four weeks of culture. (B) Appearance of some small protuberances from the leaf epidermal region. (C) Multiplication of PLBs and regeneration of large number of plantlets. (D) Showing the complete young plant (E) somatic chromosome $2 n=40$ of the root tip cells of regenerants (F) somatic chromosome $2 n=40$ of the root tip cells of mother plants. Bar $=50 \mu \mathrm{M}$. 
hormones play an important role in vitro propagation of many orchid species (Arditti \& Ernst 1993). In the present experiment, for young leaf explants, NAA was used as only auxin at the concentration of $0.5 \mathrm{mg} / \mathrm{l}, 1$ $\mathrm{mg} / \mathrm{l}$ and $2 \mathrm{mg} / \mathrm{l}$ in combination with Kinetin or BAP used as cytokinin. Differences in the induction rate for PLBs were observed between the treatments with $\mathrm{Kn}$ and the BAP in combination with NAA. Comparatively, $\mathrm{Kn}$ gave a superior response to BAP for inducing PLBs in young leaf tissue of C. flaccida. In this study, $\mathrm{Kn}$ at a particular concentration $(2 \mathrm{mg} / \mathrm{l})$ along with $2 \mathrm{mg} / \mathrm{l} \mathrm{NAA}$ in combination strongly stimulated the formation of more PLBs. Kn facilitated conversion of more than $90 \%$ PLBs to shoots in foliar explants of Dendrobium (Martin et al. 2006). Effective stimulation of NAA and Kn on PLB formation is also in agreement with the observations in Rhynchostylis retusa (L.) Blume (Vij et al. 1984), Coelogyne punctulata Lindl. (Sharma \& Tandon 1986), Acampe praemorsa (Roxb.) Blatt. \& McCann (Nayak et al. 1997), Ascocenda 'kangla'(Kishor et al. 2006), Vanda testacea (Lindl.) Rchb. f. (Kaur \& Bhutani 2009), Cymbidium mastersii Griff. ex Lindl. (Mohanty et al. 2012), and Coelogynae flaccida (Kaur \& Bhutani 2013).

In the present culture, regeneration response in most of the cases is restricted to the basal region of the leaf whereas in few cases the leaves regenerated all along the surface. Development of PLBs at the base of leaves was similar to that in Cattleya. In Cattleya, the meristematic area which forms PLBs, are in the epidermal cells of the basal region of the leaf (Arditti 1977a, 1977b, Pierik 1989).The same is true of Aranda (Loh et al. 1975). The restriction of such an activity in the leaf base may be associated with the genetic makeup and physiological age of the explant,and/or the medium being employed (Vij et al. 1984). Rhynchostylis retusa, the initiation of PLBs formation was in the upper and lower epidermal cells near the basal ends of the explants. The entire surface of the juvenile leaf is potentially meristematic in Rhynchostylis retusa and Phalaenopsis amabilis (L.) Blume (Vij et al.1984, Chen et al. 2006). The potential adventives meristematic cells undergo repeated mitotic cycles and subsequently develop into PLBs.

The cytological uniformity in the root cells of the regenerants and mother plant in terms of chromosome number in the present cultures can be correlated with their origin from the epidermal layers. According to Dulieu (1972), the plants regenerated from epidermal layers are cytologically more stable and generally remain diploid. This has been corroborated in subsequent studies (Loh et al. 1975; Vij et al. 1984; Vij \& Pathak 1990).

In conclusion, an efficient and rapid in vitro protocol for direct plant regeneration has been achieved from the foliar explants of $C$. flaccida, an endangered orchid of high medicinal and horticultural value. Plant establishment can be successfully completed after 8 months following the development of aseptic plantlets derived from aseptically seed germination under in vitro condition. The efficiency of $\mathrm{Kn}$ at the concentration of $2 \mathrm{mg} / \mathrm{l}$ in combination with NAA $(2 \mathrm{mg} / \mathrm{l})$ in terms of regeneration response and the number of plantlets regeneration per foliar explants of C. flaccida after 15 weeks were found better than that of same concentration of NAA and BAP used for the same purpose. Healthy plantlets developed from PLBs of foliar explants survived well when transplanted in the greenhouse. This protocol is simple, easy to carry out without damaging or further endangering the existing natural plant population and can provide a large number of plants for mass propagation. and conservation in their wild habitat. We expect that this ability will also open up the prospect of using biotechnological approaches for C. flaccida improvement.

Acknowledgements. We acknowledge the Department of Botany, Presidency College, Kolkata, West Bengal for providing the excellent laboratory facilities for this type of work. We should also like to thank Prof. Samir Kumar Mukhopadhyay, Head of English Department, Hooghly Mohsin College who carefully read the manuscript and made the necessary corrections of the manuscript.

\section{LiterATURE CITED}

Arditti, J. (1977a). Clonal propagation of orchids by means of leaf culture in vitro: a short review. The Orchid Review, $85,202-203$.

Arditti, J. (1977b). Clonal propagation of orchids by means of tissue culture - a manual. In: J. Arditti (ed.), Orchid Biology: Review and Perspectives vol. 1 (pp. 203-293). New York: Cornell University Press.

Arditti, J. \& Ernst, R. (1993). Micropropagation of Orchids. New York: John Wiley \& Sons. 
Bailes, C. P. (1985). Orchids in Nepal, the conservation and development of a natural resource, advisory report and recommendations. Kew: Royal Botanic Gardens.

Chen, J. T. \& Chang, W. C. (2006). Direct somatic embryogenesis and plant regeneration from leaf explants of Phalaenopsis amabilis. Biologia Plantarum, 50, 169-173.

Chen, J. T., Chang, C. \& Chang, W. C. (1999). Direct somatic embryogenesis on leaf explants of Oncidium Gower Ramsey and subsequent plant regeneration. Plant Cell Reports, 19, 143-149.

Chen, T. Y., Chen, J. T. \& Chang, W. C. (2004). Plant regeneration through direct shoot bud formation from leaf cultures of Paphiopedilum orchids. Plant Cell, Tissue and Organ Culture, 76, 11-15.

Clayton, D. (2002). The genus Coelogyne, a synopsis. Kew: Royal Botanic Gardens.

Dulieu, H. (1972). The combination of cell and tissue culture with mutagenesis for the induction and isolation of morphological or developmental mutants. Phytomorph, 22, 283-296.

Gow, W. P., Chang, W. C. \& Chen, J. T. (2009). Enhancement of direct somatic embryogenesis and plant growth from leaf explants of Phalaenopsis by adjusting culture period and explants length. Acta Physiologiae Plantarum, 32, 621-627.

Hong, P. I., Chen, J. T. \& Chang, W. C. (2008). Plant regeneration via protocorm-like body formation and shoot multiplication from seed-derived callus of a maudiae type slipper orchid. Acta Physiologiae Plantarum, 30,755-759.

Huang, C. H. \& J. P. Chung. (2010). Efficient indirect induction of protocorm-like bodies and shoot proliferation using field-grown axillary buds of a Lycaste hybrid. Plant Cell, Tissue and Organ Culture, 106,31-38.

Kai, G. Y., Dai, L. M., Mei, X. Y., Zheng, J. G., Qian, Z. Y. \& Zhon, G. Y. (2008). In vitro plant regeneration from plant leaf explants of Ophiorrhiza japonica. Biologia Plantarum, 52, 557-560.

Kaur, S. \& Bhutani, K. K. (2009). In vitro propagation of Vanda testacea (Lindl.) Reichb.f.- a rare orchid of high medicinal value. Plant Tissue Culture \& Biotechnology, 19, 1-7.

Kaur, S. \& Bhutani, K. K. (2013). In vitro conservation and asymbiotic propagation of Coelogyne flaccida (Lindl.): a threatened orchid. Plant Biosystems, 147, 935-944. doi: 10.1080/11263504.2013.801368.

Kishor, R. \& Devi, S. (2009). Induction of multiple shoots in a monopodial orchid hybrid (Aerides vandarum Reichb.f $\times$ Vanda stangeana Reichb.f) using thidiazuron and analysis of their genetic stability. Plant Cell, Tissue and Organ Culture, 97, 121-129.

Lee, S. K. \& Phillips, R. L. (1988). The chromosomal basis of somaclonal variation. Annual Review of Plant Physiology and Plant Molecular Biology, 39, 413-437.

Liau, C. H., You, S. J., Prasad, V., Hsiao, H. H., Lu, J.
C., Yang, N. S. \& Chan, M. T. (2003). Agrobacterium tumefaciens-mediated transformation of an Oncidium orchid. Plant Cell Reports, 21, 993-998.

Loh, C. S., Rao, A. N. \& Goh, C. J. (1975). Clonal propagation from leaves in the orchid Aranda. Journal of The Singapore National Academy of Science, 4, 97-99.

Luo, J. P., Wang, Y., Zha, X. Q. \& Huang, L. (2008). Micropropagation of Dendrobium densiflorum Lindl. ex Wall. through protocorm-like bodies: effects of plant growth regulators and lanthanoids. Plant Cell, Tissue and Organ Culture, 93, 333-340.

Majumdar, P. L., Banerjee, S., Maiti, D. C. \& Sen, S. (1995). Stilbenoides from the orchids Agrostophyllum callosum and Coelogyne flaccida. Phytochemistry, 39, 649-653.

Martin, K. P. \& Madassery, J. (2006). Rapid in vitro propagation of Dendrobium hybrids through direct shoot formation from foliar explants, and protocorm-like bodies. Scientia Horticulturae, 108, 95-99.

Mayer, J. L. S., Stancato, G. C. \& Glória, B. A. D. (2010). Direct regeneration of protocorm-like bodies (PLBs) from leaf apices of Oncidium flexuosum Sims (Orchidaceae). Plant Cell, Tissue and Organ Culture, 103, 411-416.

Mohanty, P., Paul, S., Das, M. C., Kumaria, S. \& Tandon, P. (2012). A simple and efficient protocol for the mass propagation of Cymbidium mastersii: an ornamental orchid of Northeast India. AoB PLANTS, pls023. doi: 10.1093/aobpla/pls023.

Morel, G. M. (1974). Clonal multiplication of orchids. In: C. L. Whitner (Ed.), The Orchids: Scientific Studies (pp. 169-122). New York: John Wiley \& Sons.

Murashige, T. \& Skoog F. (1962). A revised medium for rapid growth and bioassays with tobacco tissue cultures. Physiologia Plantarum, 15, 473-493.

Naing, A. H., Chung, D. J. \& Lim, K. B. (2011). Plant regeneration through indirect somatic embryogenesis in Coelogyne cristata orchid. American Journal of Plant Science, 2, 262-267.

Nayak, N. R., Rath, S. P. \& Patnaik, S. (1997). In vitro propagation of three epiphytic orchids, Cymbidium aloifolium (L.) Sw., Dendrobium aphyllum (Roxb.) Fisch. and Dendrobium moschatum (Buch-Ham) Sw. through thiazurion-induced high frequency shoot proliferation. Scientia Horticulturae, 17, 243-250.

$\mathrm{Ng}$, C. Y. \& Saleh, N. M. (2011). In vitro propagation of Paphiopedilum orchid through formation of protocorm-like bodies. Plant Cell, Tissue and Organ Culture, 105, 193-202.

Park, S. Y., Murthy, H. N. \& Paek, K. Y. (2002). Rapid propagation of Phalaeonopsis from floral stalk-derived leaves. In vitro Cellular \& Developmental Biology Plant, 38, 168-172.

Pathak, P. \& Vij, S. P. (2001). In vitro regeneration of Papilionanthe teres (Roxb.) Schltr.: Utility of foliar explants. In: H. Nagatha \& S. Ichihashi (Eds.), Proc. $7^{\text {th }}$ 
Asia Pacific Orchid Conference Organizing Committee (pp. 226-227). Nagoya: APOC7.

Pierik, R. L. M. (1989). In vitro culture of higher plants. Leiden: Martinus Nijhoff Publishers.

Rajbhandari, K. R. \& Bhattarai, S. (2001). Beautiful orchids of Nepal. Kathmandu: Kishor Offset Press.

Seeni, S. \& Latha, P. G. (1992). Foliar regeneration of the endangered red Vanda. Plant Cell, Tissue and Organ Culture, 29, 167- 172.

Seeni, S. \& Latha, P. G. (2000). In vitro multiplication and ecorehabilitation of the endangered blue Vanda. Plant Cell, Tissue and Organ Culture, 61, 1-8.

Sharma, S. K. \& Tandon, P. (1986). Influence of growth regulators on asymbiotic germination and early seedling development of Coelogyne punctulata Linl. In: S. P. Vij (Ed.), Biology, conservation and culture of orchids (pp. 441451). New Delhi: Affiliated East-West Press Private Limited.

Sheelavanthmath, S. S., Murthy, H. N., Hema, B. P., Hahn, E. J. \& Paek, K. Y. (2005). High frequency of protocorm like bodies (PLBs) induction and plant regeneration from protocorm and leaf sections of Aerides crispum. Scientia Horticulturae, 106, 395-401.

Sreeramanan, S., Vinod, B. Sashi, S. \& Xavier, R. (2008). Optimization of the transient-gusa gene transfer of Phalaenopsis violacea orchid via Agrobacterium tumefaciens: an assessment of factors influencing the efficiency of gene transfer mechanisms. Advances in Natural Applied Sciences, 2, 77-88.
Vij, S. P. \& Aggarwal, S. (2003). Regeneration competence of foliar explants: Vanda coerulea Griff. Journal of the Orchid Society of India, 17, 73-78.

Vij, S. P., Kaur, P., Kondo, K., Pathak, P. \& Gupta, A. (2002). Regeneration competence of Orchid leaves: A study in vitro. In: S. P. Vij, K. Kondo, M. L. Sharma \& A.Gupta (Eds.), Plant Genetic Diversity: Exploration, Evaluation, Conservation (pp. 289-306). New Delhi: Affiliated EastWest Press.

Vij, S. P., Kher, A. \& Gupta, A. (2000). Orchid micropropagation. In: K. L. Chadha, P. N. Ravindran \& L. Sahijram (Eds.), Biotechnology in horticultural and plantation crops (pp. 598-641). New Delhi: Malhotra Publishing House.

Vij, S. P. \& Pathak, P. (1990). Micropropagation of orchids through leaf segments. Journal of the Orchid Society of India, 4, 69-88.

Vij, S. P., Sood, A. \& Plaha, K. K. (1984). Propagation of Rhynchostylis retusa by direct organogenesis from leaf segment cultures. Botanical Gazette, 145, 210-114.

Wu, C. Y., Raven, P. H. \& Hong, D. Y. (2009). Flora of China Vol.-25 (Orchidaceae). Missouri: Missouri Botanical Garden Press.

Zhao, P., Wu, F., Feng, F. S. \& Wang, W. J. (2008). Protocorm-like body (PLB) formation and plant regeneration from the callus culture of Dendrobium candidum Wall ex Lindl. In Vitro Cellular and Developmental Biology - Plant, 44, 178-185. 